\title{
A study on lipid metabolism in heart and liver of cholesterol- and pectin-fed rats
}

\author{
BY SOFIE HEXEBERG ${ }^{1}$, ERIK HEXEBERG ${ }^{2}$, NINA WILLUMSEN ${ }^{3}$ \\ AND ROLF K. BERGE \\ ${ }^{1}$ Department of Anatomy and Cell Biology, University of Bergen, Arstadveien 19, \\ N-5009 Bergen, Norway \\ ${ }^{2}$ Department of Surgery and ${ }^{3}$ Department of Clinical Biology, Division of Biochemistry, \\ University of Bergen, Haukeland Sykehus, $N$-502I Bergen, Norway
}

(Received 20 November 1992 - 17 February 1993 - Accepted 18 March 1993)

\begin{abstract}
Pectin is known as a cholesterol-reducing dietary fibre, and in the present study we addressed the question whether pectin affected the quantity of lipid in droplets in the myocardial cells and of lipid in the liver cells. Male Wistar rats received either a diet containing cholesterol or a standard diet without cholesterol with 0,50 or $100 \mathrm{~g}$ pectin/ $\mathrm{kg}$ incorporated for $10 \mathrm{~d}$. The fractional volume of lipid droplets in the myocardial cells decreased as a function of pectin dose in both the standard-fed and the cholesterolfed rats. Serum cholesterol was significantly reduced in both groups after addition of $100 \mathrm{~g} \mathrm{pectin} / \mathrm{kg}$ diet. The cholesterol diet increased the liver cholesterol level, and $100 \mathrm{~g} \mathrm{pectin} / \mathrm{kg}$ diet resulted in a lower concentration of liver cholesterol in the cholesterol-fed animals, but the influence on standard-fed rats was modest. Hydroxymethylglutaryl-CoA reductase (EC 1.1.1.88; HMG-CoA reductase) activity increased when pectin was given in the standard diet. Liver triacylglycerol level increased after cholesterol and pectin feeding. Mitochondrial fatty acid oxidation and phosphatidate phosphohydrolase $(E C 3.1 .3 .4)$ activity tended to decrease, whereas the peroxisomal fatty acid oxidation and acyl-CoA oxidase activity were unchanged. Increased hepatic triacylglycerol content by cholesterol and pectin treatment may be due to inhibited mitochondrial fatty acid oxidation along with increased availability of fatty acid for esterification and triacylglycerol synthesis. The presence of pectin in the diets of cholesterol-fed rats resulted in increased hepatic concentration of triacylglycerols and increased mitochondrial fatty acid oxidation. In this case the hepatic accumulation of triacylglycerol may be mediated by a reduced efflux of triacylglycerols from the liver.
\end{abstract}

Pectin: Cholesterol: Cardiomyocytes: Rat

A prominent feature of atherosclerosis is marked accumulation of cholesterol esters and other lipids in the arterial wall (Orekhov et al. 1985, 1987; Fuster et al. 1992; Tertov et al. 1992). These lipids are observed as droplets in the endothelial cells (Orekhov et al. 1985). The mechanism behind this arterial lipidosis is probably linked to the uptake of low-density lipoproteins (LDL) from the plasma (Orekhov et al. 1987; Tertov et al. 1992). The cholesterol-lowering effect of dietary fibres is well documented (Judd \& Truswell, 1985; Anderson, 1986; Madar \& Thorne, 1987; Kritchevsky, 1988). However, the possible ultrastructural changes in myocardial cells brought about by varying the dietary content of cholesterol and fibre have not gained any particular attention. We recently demonstrated by morphometric methods that a high-cholesterol diet induced lipid droplet accumulation in the cardiomyocytes of rats (Hexeberg et al. 1993). It was of interest, therefore, to study whether a reduction in serum cholesterol by dietary pectin would lead to a reduced quantity of lipid in droplets in myocardial cells of standard- and cholesterol-fed rats. This was the first aim of the study. 
The mechanism behind the cholesterol-lowering effect of dietary fibre has not been fully elucidated. Results from studies on experimental animals seem to indicate that several mechanisms might be operative. Acceleration of cholesterol catabolism through increased cholesterol $7 \alpha$-hydroxylase (EC 1.14.13.17) activity or inhibition of cholesterol synthesis have been suggested.

Feeding with pectin has been reported to reduce both serum triacylglycerols and hepatic triacylglycerols (Chen et al. 1981; Vigne et al. 1987; Nishina et al. 1991). Reduced hepatic lipogenesis, retarded very-low-density lipoprotein (VLDL) secretion and enhanced fatty acid oxidation (mitochondrial and peroxisomal) may be the operative mechanisms. The possibility that reduced synthesis of triacylglycerols induced by water-soluble fibres might be due to an inhibition of one or more of the enzymes involved in triacylglycerol biosynthesis, therefore, should be addressed. The second aim of the study was to elucidate mechanisms related to lipid metabolism, especially whether pectin feeding had triacylglycerol- and cholesterol-lowering effects, and whether pectin feeding had any influence on the mitochondrial and peroxisomal $\beta$-oxidation in standard- and cholesterol-fed rats. Furthermore, the two dietary models (standard-fed rats and cholesterol-fed rats) were used to investigate the effect of pectin feeding on the rate-limiting enzymes of triacylglycerol synthesis (phosphatidate phosphohydrolase; EC 3.1.3.4) and cholesterol synthesis (hydroxymethylglutaryl-CoA reductase; EC 1.1.1.88; HMG-CoA reductase).

\section{MATERIALS AND METHODS}

\section{Animals, diet and treatment}

Male Wistar rats (6 weeks old) from Mollegaard Breeding Laboratory, Ejby, Denmark, were acclimated for at least 1 week before the experiment started. Groups of three rats were housed in wire cages in a room with a constant temperature of $20 \pm 3^{\circ}$ and maintained on $12 \mathrm{~h}$ light-dark cycles. The animals were fed on a standard diet in this period (Table 1). To study the effects of pectin, both a standard (S) and a cholesterol (C) diet were used in the experiment. Thirty rats were randomly assigned to eight different groups. The two control groups ( $\mathrm{S} 0$ and $\mathrm{C} 0$ ) consisted of six rats each, whereas the other groups included three rats each. The groups S0, S50, S100 and S150 were fed on a standard diet to which $0,50,100$ and $150 \mathrm{~g}$ pectin $/ \mathrm{kg}$ were added (Table 1). The groups $\mathrm{C} 0, \mathrm{C} 50, \mathrm{C} 100$ and $\mathrm{C} 150$ received a cholesterol diet ( $20 \mathrm{~g}$ cholesterol $/ \mathrm{kg}$ ) to which $0,50,100$ and $150 \mathrm{~g}$ pectin $/ \mathrm{kg}$ were added. The diets were identical with respect to sucrose, protein, fat, vitamins and minerals. The cholesterol and pectin were incorporated into the standard diet to substitute for an equal amount of starch. The food was given as porridge, and both food and water were available ad lib. Body weights were recorded at the beginning of the experiment and after $10 \mathrm{~d}$ feeding. The rats were anaesthetized with Hypnorm (Janssens Pharmaceutica, Berse, Belgium) and Dormicum (La Roche AG, Basel, Switzerland) given subcutaneously in the morning on the eleventh day after having been fasted for $12 \mathrm{~h}$ overnight. The heart was punctured, and blood was withdrawn into a heparinized syringe and centrifuged. The heart and liver were quickly removed and weighed. One slice was cut through the middle of the heart for electron microscopic preparation. The Norwegian State Commission for Experiments with Animals approved the protocol.

\section{Preparation of total homogenate and the different subcellular fractions}

The livers from individual rats were homogenized in ice-cold sucrose medium $(0.25$ mol sucrose/ 1 in $10 \mathrm{~mm}$-Hepes buffer, $\mathrm{pH} 7 \cdot 4$, and $2 \mathrm{mm-EDTA}$ ) and the postnuclear fraction was prepared from the total homogenate by centrifuging at $3000 \mathrm{~g}$ for $10 \mathrm{~min}(\mathrm{HB}-4$ rotor; 
Table 1. Composition of diets $(\mathrm{g} / \mathrm{kg})$

\begin{tabular}{|c|c|c|c|c|c|c|c|c|}
\hline & \multicolumn{4}{|c|}{ Standard diet (S) } & \multicolumn{4}{|c|}{$20 \mathrm{~g}$ cholesterol $/ \mathrm{kg}$ diet $(\mathrm{C})$} \\
\hline & So & $\mathrm{S} 50$ & $\mathrm{~S} 100$ & $\mathrm{~S} 150$ & $\mathrm{CO}$ & $\mathrm{C} 50$ & $\mathrm{C} 100$ & $\mathrm{C} 150$ \\
\hline Cholesterol* & 0 & 0 & 0 & 0 & 20 & 20 & 20 & 20 \\
\hline Pectint & 0 & 50 & 100 & 150 & 0 & 50 & 100 & 150 \\
\hline Starch & $586 \cdot 5$ & $536 \cdot 5$ & $486 \cdot 5$ & $436 \cdot 5$ & $566 \cdot 5$ & $516 \cdot 5$ & 466.5 & $416 \cdot 5$ \\
\hline Sucrose & 110 & 110 & 110 & 110 & 110 & 110 & 110 & 110 \\
\hline Soya-bean concentrate $\ddagger$ & 193.5 & $193 \cdot 5$ & 193.5 & 193.5 & $193 \cdot 5$ & $193 \cdot 5$ & 193.5 & $193 \cdot 5$ \\
\hline Soya-bean oil & 50 & 50 & 50 & 50 & 50 & 50 & 50 & 50 \\
\hline Vitamin $\operatorname{mix} \S$ & 10 & 10 & 10 & 10 & 10 & 10 & 10 & 10 \\
\hline Mineral mix $\|$ & 30 & 30 & 30 & 30 & 30 & 30 & 30 & 30 \\
\hline Cellulose & 20 & 20 & 20 & 20 & 20 & 20 & 20 & 20 \\
\hline
\end{tabular}

S0, C0; S50, C50; S100, C100; S150, C150, diets contained $0,50,100$ and $150 \mathrm{~g}$ pectin $/ \mathrm{kg}$ respectively.

* Sigma Chemical Co.; ash-free, precipitated from alcohol, $950-980 \mathrm{~g} / \mathrm{kg}$.

$\dagger$ Sigma Chemical Co.; from citrus fruits.

$\$$ Contained $620 \mathrm{~g}$ protein $/ \mathrm{kg}$.

$\S$ Contained $(\mathrm{mg} / \mathrm{kg})$ : vitamin A 800 , vitamin D 200, vitamin E $(500 \mathrm{mg} / \mathrm{g}) 6000$, vitamin $\mathrm{K}(500 \mathrm{mg} / \mathrm{g}) 10$, choline 100, pteroylmonoglutamic acid 100, niacin 2000, pantothenic acid 800 , riboflavin 300 , thiamin 400 , pyridoxine 600 , cyanocobalamin $(10 \mathrm{mg} / \mathrm{g}) 500$, dextrin to $1 \mathrm{~kg}$.

Contained $\left(\mathrm{g} / \mathrm{kg}: \mathrm{CaCO}_{3} 282 \cdot 87, \mathrm{CaHPO}_{4} \cdot 2 \mathrm{H}_{2} \mathrm{O} 208 \cdot 64, \mathrm{KH}_{2} \mathrm{PO}_{4} 409 \cdot 57, \mathrm{MgCO}_{3} 45 \cdot 52, \mathrm{NaCO}_{3}\right.$ 13.43, $\mathrm{NaCl} 26 \cdot 70, \mathrm{CuSO}_{4} .5 \mathrm{H}_{2} \mathrm{O} 0 \cdot 63, \mathrm{NaF} 0 \cdot 073, \mathrm{KI} 0.0065, \mathrm{FeSO}_{4} .7 \mathrm{H}_{2} \mathrm{O} 5 \cdot 69, \mathrm{MnSO}_{4} . \mathrm{H}_{2} \mathrm{O} 5 \cdot 01, \mathrm{Na}_{2} \mathrm{SeO}_{3} 0 \cdot 0066$, $\mathrm{ZnSO}_{4} \cdot 7 \mathrm{H}_{2} \mathrm{O} 1 \cdot 73$.

Sorvall Instruments, Du Pont Company, Wilmington, Delaware 19898, USA). The resulting nuclear plus postnuclear fractions were used as the total homogenate. For further analysis of postnuclear fractions differential centrifugation samples from three animals were pooled, and a mitochondrial-enriched fraction, microsomal fraction, and cytosolic fraction were isolated (Berge et al. 1987).

\section{Enzyme assays and other analytical methods}

The variation in the response from animal to animal was estimated separately for selected enzymes in the postnuclear fractions. The enzymic activity of palmitoyl-CoA hydrolase (EC 3.1.2.2; Berge \& Farstad, 1979), palmitoyl-CoA synthetase (EC 6.2.1.3; Aas \& Daae, 1971), palmitoyl-CoA-dependent dehydrogenase (usually termed peroxisomal $\beta$ oxidation); Berge et al. 1984), fatty acyl-CoA oxidase (Small et al. 1985), phosphatidate phosphohydrolase (Mavis et al. 1978), and HMG-CoA reductase (Brown et al. 1979), were determined as previously described. Palmitoyl-CoA and palmitoyl-L-carnitine oxidation were evaluated by measuring appearance of acid-soluble products (Skorve et al. 1990). Protein was determined by the Bio-Rad protein assay kit (BioRad Laboratories, Richmond, CA, USA). All the spectrophotometric measurements were performed with a Varian 2300 spectrophotometer. Lipid analyses were carried out using the monotest cholesterol enzymic kit (Boehringer, Mannheim, Germany), the biopack triacylglycerol enzymic kit (Biotrol, Paris, France), and the phospholipid enzymic kit, PAP 150 (BioMerieux, Marcy l'Etoile, France).

\section{Tissue preparation for electron microscopy}

The heart slices were submerged in ice-cold modified Karnovsky's fixative. The fixative contained (/1): $20 \mathrm{~g}$ paraformaldehyde and $25 \mathrm{~g}$ glutaraldehyde in $0 \cdot 1 \mathrm{M}$-cacodylate buffer with $0.1 \mathrm{M}$-sucrose and $1.25 \mathrm{~mm}-\mathrm{CaCl}_{2}$ ( $\mathrm{pH} 7.4$ and vehicle osmolality 300 mosmol). Specimens for electron microscopy were excised from the anterior side of the left ventricle from each heart. All specimens were immersion-fixed for at least $3 \mathrm{~h}$, then washed in cacodylate buffer (vehicle osmolality $300 \mathrm{mosmol} / \mathrm{kg}$ ), and post-fixed in $\mathrm{OsO}_{4}$ solution 
$(10 \mathrm{~g} / 1)$ of the same buffer before they were dehydrated in ethanol and embedded in Epon (EPON 812; SERVA Feinbiochemica, Heidelberg, Germany). Ultrathin (50-75 nm) sections stained for $1 \mathrm{~h}$ with uranyl acetate and $15 \mathrm{~min}$ with lead citrate were used for electron microscopy. From each animal two different specimens were used. Five micrographs were chosen randomly from each specimen, and examined at a final magnification of $\times 9600$. In each micrograph we calculated the fractional volume of lipid droplets, defined as the percentage of lipid droplets relative to cytoplasm. A grid lattice with a distance of $5 \mathrm{~mm}$ between the lines was used for calculation of the fractional volume of lipids. All morphometric measurements were performed with the lines in the grid lattice both at $0^{\circ}$ and $15^{\circ}$ to the edges of the micrographs. This was done to minimize the effect of any possible anisotropy in the plane. The mean of the two values obtained at both angles in each micrograph was used. The point-counting was performed by two observers separately, and the morphometric data were collected blindly. The interobserver variability was less than $5 \%$.

\section{Study design and statistical analysis}

In the feeding period it was observed that the rats receiving a diet with $150 \mathrm{~g}$ pectin $/ \mathrm{kg}$ ate less than the other rats. The weight gain in the $150 \mathrm{~g}$ pectin $/ \mathrm{kg}$ groups $(2 \mathrm{~g}$ and $7 \mathrm{~g}$ for $\mathrm{S} 15$ and $\mathrm{C} 15$ respectively) were significantly lower than the weight gain in the groups which received 0,50 , and $100 \mathrm{~g}$ pectin $/ \mathrm{kg}$ in both standard- and cholesterol-fed rats. The two $150 \mathrm{~g}$ pectin $/ \mathrm{kg}$ groups, therefore, were excluded before further analysis.

The groups analysed were the following: standard-fed rats which received 0,50 , or $100 \mathrm{~g}$ pectin $/ \mathrm{kg}(\mathrm{S} 0, \mathrm{~S} 50, \mathrm{~S} 100)$, and cholesterol-fed rats which received 0,50 , or $100 \mathrm{~g}$ pectin $/ \mathrm{kg}$ (C0, C50, C100).

The effects of pectin and cholesterol supplements in the diet were tested by a two-way analysis of variance. The probability values are given in the tables, and $P<0.05$ is used as the level of statistical significance.

\section{RESULTS}

\section{Presentation of the results}

The results are presented as means with their standard errors. For isolation of cellular fractions from livers the postnuclear fractions in each group were pooled. The tabulated values on enzyme activities in cellular fractions of the livers are given as mean values for up to six measurements.

\section{Body, liver and heart weights}

Rats fed on standard and cholesterol diets supplemented with 0,50 , and $100 \mathrm{~g}$ pectin $/ \mathrm{kg}$ gained weight in a comparable manner (Table 2). The relative liver weights were greater in the cholesterol-fed rats than the standard-fed rats $(P=0.024)$, but were not altered by pectin feeding. No differences in the liver weights, heart weights or relative heart weights between the groups were observed.

\section{Serum and liver lipids}

The effects of pectin and cholesterol on serum lipids in rats fed on standard and cholesterol diets are presented in Table 3 . The cholesterol diet $(20 \mathrm{~g} / \mathrm{kg})$ did not increase the serum cholesterol level after $10 \mathrm{~d}$ feeding. However, the serum cholesterol was significantly reduced in both the standard-fed rats and the cholesterol-fed rats after addition of $100 \mathrm{~g}$ pectin $/ \mathrm{kg}$ to the diet. The high-density-lipoprotein (HDL) cholesterol tended to decrease as a function of pectin dose in the standard-fed rats, but it did not reach statistical significance. The HDL-cholesterol level was unaltered in the cholesterol-fed rats. The HDL-cholesterol:total cholesterol value also remained unchanged irrespective of the 
Table 2. Effects of dietary pectin (Pe) and cholesterol $(\mathrm{Ch})$ on body, liver and heart weights of rats fed on standard $(S)$ and $20 \mathrm{~g}$ cholesterol $/ \mathrm{kg}(C)$ diets*

(Mean values with their standard errors for six rats/group for $0 \mathrm{~g}$ pectin $/ \mathrm{kg} \mathrm{S}$ and $\mathrm{C}$ treatment groups and three rats/group for the other treatment groups)

\begin{tabular}{|c|c|c|c|c|c|c|c|c|c|c|}
\hline \multirow[t]{2}{*}{$\begin{array}{l}\text { Dietary pectin } \\
(\mathrm{g} / \mathrm{kg}) \ldots\end{array}$} & \multirow{2}{*}{$\begin{array}{l}\text { Treatment } \\
\text { group }\end{array}$} & \multicolumn{2}{|c|}{0} & \multicolumn{2}{|c|}{50} & \multicolumn{2}{|c|}{100} & \multicolumn{3}{|c|}{$\begin{array}{c}\text { Significance of effects } \\
\text { in analysis of } \\
\text { variance }(P=)\end{array}$} \\
\hline & & Mean & $\mathrm{SE}$ & Mean & $\mathrm{SE}$ & Mean & $\mathrm{SE}$ & $\mathrm{Ch}$ & $\mathrm{Pe}$ & $\mathrm{Ch} \times \mathrm{Pe}$ \\
\hline \multirow[t]{2}{*}{ Initial body wt (g) } & $\mathrm{S}$ & 196 & 3.0 & 194 & $1 \cdot 7$ & 196 & 6.7 & \multirow[t]{2}{*}{0.003} & \multirow[t]{2}{*}{0.892} & \multirow[t]{2}{*}{0.651} \\
\hline & $\mathrm{C}$ & 204 & $2 \cdot 9$ & 210 & $3 \cdot 5$ & 206 & $5 \cdot 8$ & & & \\
\hline \multirow[t]{2}{*}{ Final body wt (g) } & $\mathrm{S}$ & 219 & $6 \cdot 8$ & 225 & $5 \cdot 0$ & 221 & $12 \cdot 7$ & \multirow[t]{2}{*}{0.484} & \multirow[t]{2}{*}{0.926} & \multirow[t]{2}{*}{$0 \cdot 815$} \\
\hline & $\mathrm{C}$ & 226 & $5-1$ & 224 & $2 \cdot 0$ & 228 & $1 \cdot 2$ & & & \\
\hline \multirow[t]{2}{*}{ Wt gain (g) } & $\mathrm{S}$ & 23 & $4 \cdot 5$ & 31 & $6 \cdot 7$ & 25 & $7 \cdot 1$ & \multirow[t]{2}{*}{0.09} & \multirow[t]{2}{*}{0.98} & \multirow[t]{2}{*}{0.29} \\
\hline & $\mathrm{C}$ & 22 & $3 \cdot 1$ & 14 & $3 \cdot 7$ & 22 & 4.9 & & & \\
\hline \multirow[t]{2}{*}{ Liver wt (g) } & $\mathrm{S}$ & $6 \cdot 30$ & 0.276 & $6 \cdot 87$ & 0.596 & $7 \cdot 19$ & 0.884 & \multirow[t]{2}{*}{$0 \cdot 054$} & \multirow[t]{2}{*}{0.328} & \multirow{2}{*}{0.841} \\
\hline & $\mathrm{C}$ & $7 \cdot 47$ & $0-355$ & $7 \cdot 44$ & $0 \cdot 834$ & $8 \cdot 13$ & 0.445 & & & \\
\hline \multirow{2}{*}{$\begin{array}{l}\text { Relative liver wt } \\
\text { (mg/g body wt) }\end{array}$} & $\mathrm{S}$ & $28 \cdot 7$ & 0.55 & $30 \cdot 4$ & $2 \cdot 11$ & $32 \cdot 3$ & $2 \cdot 06$ & \multirow[t]{2}{*}{0.024} & \multirow[t]{2}{*}{$0 \cdot 192$} & \multirow[t]{2}{*}{$0 \cdot 885$} \\
\hline & C & 33.0 & 1.08 & $33 \cdot 1$ & $3 \cdot 54$ & $35 \cdot 7$ & 1.94 & & & \\
\hline \multirow[t]{2}{*}{ Heart wt $(\mathrm{g})$} & $S$ & 0.74 & 0.033 & 0.82 & 0.065 & 0.75 & 0.082 & \multirow[t]{2}{*}{0.69} & \multirow[t]{2}{*}{029} & \multirow[t]{2}{*}{0.85} \\
\hline & C & 0.78 & 0.014 & 0.82 & 0.003 & 0.75 & 0.031 & & & \\
\hline \multirow{2}{*}{$\begin{array}{l}\text { Relative heart wt } \\
(\mathrm{mg} / \mathrm{g} \text { body } \mathrm{wt})\end{array}$} & $\mathrm{S}$ & $3 \cdot 5$ & 0.13 & 3.6 & 0.21 & 34 & $0 \cdot 17$ & \multirow[t]{2}{*}{0.84} & \multirow[t]{2}{*}{0.17} & \multirow[t]{2}{*}{0.94} \\
\hline & $\mathrm{C}$ & 3.5 & 004 & 3.6 & 0.03 & $3 \cdot 3$ & 0.15 & & & \\
\hline
\end{tabular}

* For details of animals and procedures, see p. 182. For details of diets, see Table 1.

Table 3. Effects of dietary pectin $(P e)$ and cholesterol $(\mathrm{Ch})$ on levels of cholesterol, highdensity-lipoprotein $(H D L)$-cholesterol, triacylglycerol and phospholipid in the serum of rats fed on standard $(S)$ and $20 \mathrm{~g}$ cholesterol/ $\mathrm{kg}(C)$ diets*

(Mean values with their standard errors for six rats/group for $0 \mathrm{~g}$ pectin $/ \mathrm{kg} \mathrm{S}$ and $\mathrm{C}$ treatment groups and three rats/group for the other treatment groups)

\begin{tabular}{|c|c|c|c|c|c|c|c|c|c|c|}
\hline \multirow[t]{2}{*}{ Dietary pectin $(\mathrm{g} / \mathrm{kg}) \ldots$} & \multirow{2}{*}{$\begin{array}{l}\text { Treatment } \\
\text { group }\end{array}$} & \multicolumn{2}{|c|}{0} & \multicolumn{2}{|c|}{50} & \multicolumn{2}{|c|}{100} & \multicolumn{3}{|c|}{$\begin{array}{c}\text { Significance of effects } \\
\text { in analysis of } \\
\text { variance }(P=)\end{array}$} \\
\hline & & Mean & SE & Mean & SE & Mean & $\mathrm{SE}$ & $\mathrm{Ch}$ & $\mathrm{Pe}$ & $\mathrm{Ch} \times \mathrm{Pe}$ \\
\hline \multirow[t]{2}{*}{ Cholesterol $(\mathrm{mmol} / \mathrm{l})$} & $\mathrm{S}$ & 1.07 & $0 \cdot 102$ & $1 \cdot 16$ & $0 \cdot 140$ & $0 \cdot 73$ & $0 \cdot 046$ & $0 \cdot 186$ & $0 \cdot 022$ & $0 \cdot 362$ \\
\hline & $\mathrm{C}$ & 0.91 & 0.086 & $1 \cdot 01$ & $0 \cdot 144$ & $0 \cdot 80$ & $0 \cdot 038$ & & & \\
\hline \multirow[t]{2}{*}{ HDL-cholesterol (mmol/l) } & $\mathrm{S}$ & 0.79 & $0 \cdot 152$ & $0 \cdot 75$ & 0.020 & 0.47 & $0 \cdot 020$ & 0.524 & 0.203 & 0.502 \\
\hline & C & 0.56 & 0.109 & 0.75 & $0 \cdot 060$ & 0.55 & 0.036 & & & \\
\hline \multirow{2}{*}{$\begin{array}{l}\text { HDL-cholesterol: total } \\
\text { cholesterol }\end{array}$} & $\mathrm{S}$ & $0 \cdot 84$ & 0.075 & $0 \cdot 65$ & 0.057 & 0.65 & $0 \cdot 043$ & 0.405 & 0.673 & $0 \cdot 178$ \\
\hline & $\mathrm{C}$ & 0.60 & $0 \cdot 09$ & $0 \cdot 66$ & $0 \cdot 005$ & 0.69 & 0.072 & & & \\
\hline \multirow[t]{2}{*}{ Triacylglyerol (mmol/l) } & $S$ & 0.46 & 0.040 & 0.48 & $0 \cdot 052$ & 0.33 & 0.069 & $0 \cdot 346$ & 0.372 & 0.533 \\
\hline & $\mathrm{C}$ & $0 \cdot 35$ & 0.062 & $0 \cdot 42$ & 0.047 & $0 \cdot 36$ & 0.095 & & & \\
\hline \multirow[t]{2}{*}{ Phospholipid (mmol/l) } & $\mathrm{S}$ & 0.99 & 0059 & 1.08 & $0 \cdot 123$ & 0.78 & 0.058 & 0.001 & 0.039 & $0 \cdot 269$ \\
\hline & $\mathrm{C}$ & 0.68 & 0.050 & $0 \cdot 82$ & 0.053 & 0.69 & 0.051 & & & \\
\hline
\end{tabular}

* For details of animals and procedures, see pp. 182-183. For details of diets, see Table 1. 
Table 4. Effects of dietary pectin $(P e)$ and cholesterol $(\mathrm{Ch})$ on hepatic lipids (nmol/g liver) in rats fed on standard $(S)$ and $20 \mathrm{~g}$ cholesterol $/ \mathrm{kg}(C)$ diets*

(Mean values with their standard errors for six rats/group for $0 \mathrm{~g}$ pectin $/ \mathrm{kg} \mathrm{S}$ and $\mathrm{C}$ treatment groups and three rats/group for the other treatment groups)

\begin{tabular}{|c|c|c|c|c|c|c|c|c|}
\hline \multirow[t]{2}{*}{ Dietary pectin $(\mathrm{g} / \mathrm{kg}) \ldots$} & \multirow{2}{*}{$\begin{array}{l}\text { Treatment } \\
\text { group }\end{array}$} & \multicolumn{2}{|c|}{0} & \multicolumn{2}{|c|}{100} & \multicolumn{3}{|c|}{$\begin{array}{c}\text { Significance of effects } \\
\text { in analysis of variance }(P=)\end{array}$} \\
\hline & & Mean & SE & Mean & SE & $\mathrm{Ch}$ & $\mathrm{Pe}$ & $\mathrm{Ch} \times \mathrm{Pe}$ \\
\hline \multirow[t]{2}{*}{ Cholesterol } & $\mathrm{S}$ & $5 \cdot 62$ & 0.530 & 4.99 & 0.369 & $0 \cdot 0001$ & 0.0007 & 0.0015 \\
\hline & $\mathrm{C}$ & $24 \cdot 01$ & $1 \cdot 385$ & 13.98 & $1 \cdot 278$ & & & \\
\hline \multirow[t]{2}{*}{ Triacylglycerol } & $S$ & $36 \cdot 02$ & $5 \cdot 851$ & $48 \cdot 09$ & $5 \cdot 518$ & 0.009 & 0.058 & 0.678 \\
\hline & $\mathrm{C}$ & $56 \cdot 57$ & $5 \cdot 930$ & $74 \cdot 36$ & $10 \cdot 39$ & & & \\
\hline \multirow[t]{2}{*}{ Phospholipids } & $\mathrm{S}$ & $18 \cdot 74$ & 0.674 & 14.91 & 1.023 & 0.95 & $0 \cdot 21$ & $0 \cdot 20$ \\
\hline & $\mathrm{C}$ & $16 \cdot 88$ & 1.894 & 16.95 & 1.617 & & & \\
\hline
\end{tabular}

* For details of animals and procedures, see pp. 182-183. For details of diets, see Table 1.

Table 5. Effects of dietary pectin $(P e)$ and cholesterol $(C h)$ on the fractional volume of lipid droplets in mycocardial cells of rats fed on standard $(S)$ and $20 \mathrm{~g}$ cholesterol $/ \mathrm{kg}(C)$ diets*

(Mean values with their standard errors for six rats/group for $0 \mathrm{~g}$ pectin $/ \mathrm{kg} \mathrm{S}$ and $\mathrm{C}$ treatment groups and three rats/group for the other treatment groups)

\begin{tabular}{|c|c|c|c|c|c|c|c|c|c|c|}
\hline \multirow[t]{2}{*}{ Dietary pectin $(\mathrm{g} / \mathrm{kg}) \ldots$} & \multirow{2}{*}{$\begin{array}{l}\text { Treatment } \\
\text { group }\end{array}$} & \multicolumn{2}{|c|}{0} & \multicolumn{2}{|c|}{50} & \multicolumn{2}{|c|}{100} & \multicolumn{3}{|c|}{$\begin{array}{c}\text { Significance of effects } \\
\text { in analysis of } \\
\text { variance }(P=)\end{array}$} \\
\hline & & Mean & SE & Mean & $\mathrm{SE}$ & Mean & $\mathrm{SE}$ & $\mathrm{Ch}$ & $\mathrm{Pe}$ & $\mathrm{Ch} \times \mathrm{Pe}$ \\
\hline $\begin{array}{l}\text { Lipid volume relative to } \\
\text { cytoplasm }\end{array}$ & $\begin{array}{l}\mathrm{S} \\
\mathrm{C}\end{array}$ & $\begin{array}{l}0 \cdot 106 \\
0.269\end{array}$ & $\begin{array}{l}0.018 \\
0.034\end{array}$ & $\begin{array}{l}0 \cdot 083 \\
0 \cdot 203\end{array}$ & $\begin{array}{l}0 \cdot 013 \\
0 \cdot 035\end{array}$ & $\begin{array}{l}0 \cdot 073 \\
0 \cdot 140\end{array}$ & $\begin{array}{l}0 \cdot 019 \\
0 \cdot 040\end{array}$ & 0.0003 & $0 \cdot 0438$ & $0 \cdot 3027$ \\
\hline
\end{tabular}

* For details of animals and procedures, see pp. 182-184. For details of diets, see Table 1.

Table 6. Effects of dietary pectin $(P e)$ and cholesterol $(C h)$ on $\beta$-oxidation of $\left[1-{ }^{14} \mathrm{C}\right]$ palmitoylL-carnitine and $\left[1-{ }^{14} \mathrm{C}\right]$ palmitoyl-CoA activity (nmol/min per $m g$ protein) in post-nuclear fractions from livers of rats fed on standard $(S)$ and $20 \mathrm{~g}$ cholesterol $/ \mathrm{kg}(C)$ diets*

(Values in the postnuclear fraction are reported as means with their standard errors for three rats in each group)

\begin{tabular}{|c|c|c|c|c|c|c|c|c|}
\hline \multirow[t]{2}{*}{ Dietary pectin $(\mathrm{g} / \mathrm{kg}) \ldots$} & \multirow{2}{*}{$\begin{array}{l}\text { Treatment } \\
\text { group }\end{array}$} & \multicolumn{2}{|c|}{0} & \multicolumn{2}{|c|}{100} & \multicolumn{3}{|c|}{$\begin{array}{l}\text { Significance of effects in } \\
\text { analysis of variance }(P=)\end{array}$} \\
\hline & & Mean & $\mathrm{SE}$ & Mean & SE & $\mathrm{Ch}$ & $\mathrm{Pe}$ & $\mathrm{Ch} \times \mathrm{Pe}$ \\
\hline Palmitoyl-L-carnitine & $\mathrm{S}$ & $\begin{array}{l}1.57 \\
0.89\end{array}$ & $\begin{array}{l}0.015 \\
0.118\end{array}$ & $\begin{array}{l}1.32 \\
1.41\end{array}$ & $\begin{array}{l}0.009 \\
0.031\end{array}$ & $0 \cdot 0015$ & 0.0630 & 0.0002 \\
\hline Palmitoyl CoA & $\begin{array}{l}\mathrm{S} \\
\mathrm{C}\end{array}$ & $\begin{array}{l}0 \cdot 77 \\
0 \cdot 89\end{array}$ & $\begin{array}{l}0.044 \\
0.095\end{array}$ & $\begin{array}{l}0.64 \\
0.80\end{array}$ & $\begin{array}{l}0 \cdot 013 \\
0.033\end{array}$ & 0.0351 & 0.0745 & 0.7269 \\
\hline
\end{tabular}

* For details of animals and procedures, see pp. 182-183. For details of diets, see Table 1. 
Table 7. Effects of dietary pectin $(P e)$ and cholesterol $(C h)$ on peroxisomal $\beta$-oxidation and fatty acyl-CoA oxidase activity (nmol/min per $m g$ protein) in liver in rats fed on standard $(S)$ and $20 \mathrm{~g}$ cholesterol $/ \mathrm{kg}(C)$ diets*

(The activity of peroxisomal $\beta$-oxidation and fatty acyl-CoA oxidase was measured in the postnuclear fraction. Values in the postnuclear fraction are reported as means with their standard errors for three rats in each group)

\begin{tabular}{|c|c|c|c|c|c|c|c|c|}
\hline \multirow[t]{2}{*}{ Dietary pectin $(\mathrm{g} / \mathrm{kg}) \ldots$} & \multirow{2}{*}{$\begin{array}{l}\text { Treatment } \\
\text { group }\end{array}$} & \multicolumn{2}{|c|}{0} & \multicolumn{2}{|c|}{100} & \multicolumn{3}{|c|}{$\begin{array}{c}\text { Significance of effects } \\
\text { in analysis of variance }(P=)\end{array}$} \\
\hline & & Mean & SE & Mean & $\mathrm{SE}$ & $\mathrm{Ch}$ & $\mathrm{Pe}$ & $\mathrm{Ch} \times \mathrm{Pe}$ \\
\hline \multirow[t]{2}{*}{ Peroxisomal $\beta$-oxidation } & $\mathrm{S}$ & $3 \cdot 52$ & $0 \cdot 415$ & $3 \cdot 52$ & 0.219 & $0 \cdot 159$ & 0.878 & $0 \cdot 869$ \\
\hline & $\mathrm{C}$ & $3 \cdot 11$ & $0 \cdot 189$ & 3.02 & $0 \cdot 300$ & & & \\
\hline \multirow[t]{2}{*}{ Fatty acyl-CoA oxidase } & $\mathrm{S}$ & $9 \cdot 64$ & 0.731 & $12 \cdot 28$ & $2 \cdot 157$ & $0 \cdot 403$ & $0 \cdot 276$ & 0.395 \\
\hline & $\mathrm{C}$ & $9 \cdot 66$ & $1 \cdot 120$ & $10 \cdot 00$ & $0 \cdot 293$ & & & \\
\hline
\end{tabular}

* For details of animals and procedures, see pp. 182-183. For details of diets, see Table 1.

amount of cholesterol and pectin in the diet. The serum triacylglycerol concentration was not influenced by the different diets. The standard-fed rats showed a greater level of serum phospholipids than the cholesterol-fed rats $(P=0.001)$. Pectin affected the serum phospholipids in both standard-fed rats and cholesterol-fed rats. Table 4 shows that addition of cholesterol to the diet increased the liver cholesterol concentration $(P<$ $0.0001)$. Pectin $(10 \mathrm{~g} / \mathrm{kg}$ diet $)$ resulted in a lower concentration of liver cholesterol in the cholesterol-fed animals, whereas the influence on standard-fed rats was modest. Liver triacylglycerol concentration increased as a result of cholesterol feeding $(P=0.009)$, and tended to increase as a result of pectin feeding $(P=0.058)$. The level of liver phospholipids was not influenced by the dietary regimen.

\section{Heart morphology}

The number of lipid droplets per micrograph varied between 0 and 10 (Plates 1 and 2). The fractional volumes of lipid in droplets in the myocardial cells are presented in Table 5. Micrographs from cholesterol-fed rats showed a greater volume of lipid in the myocardial cells compared with standard-fed rats $(P=0.0003)$. Micrographs from hearts of pectin-fed rats showed a lower fractional volume of lipid droplets in both cholesterol-fed and standard-fed rats $(P=0 \cdot 038)$.

\section{Fatty acid oxidation}

Table 6 shows that in the group fed on the cholesterol diet without pectin, oxidation of $\left[\mathrm{I}-{ }^{14} \mathrm{C}\right]$ palmitoyl-L-carnitine was significantly lower than fatty acid oxidation in the group fed on the standard diet without pectin. However, when palmitoyl-CoA was used as substrate the activity increased as a result of cholesterol feeding $(P=0.0351)$. Pectin feeding tended to decrease the fatty acid oxidation in the standard-fed rats and the cholesterol-fed rats $(P=0.0745)$. Pectin neither increased peroxisomal $\beta$-oxidation nor acyl-CoA oxidase activity in the two dietary models (Table 7). Addition of cholesterol to the diet did not seem to inhibit the peroxisomal $\beta$-oxidation as the peroxisomal enzyme activities for the group fed on the cholesterol diet were not significantly different from the group fed on the standard diet. 


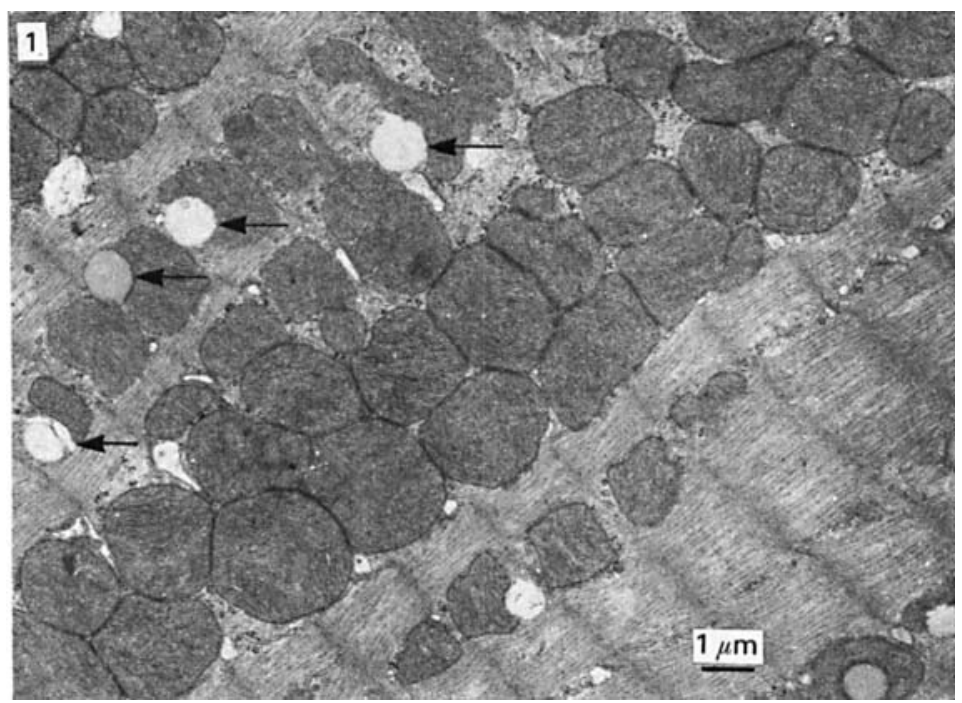

Plate 1. Myocardium from a rat fed on a $20 \mathrm{~g}$ cholesterol $/ \mathrm{kg}$ diet (for details, see Table 1 and $\mathrm{p}$. 187). Numerous lipid droplets are seen $(\downarrow) .1 / \mathrm{m}(\times 9600)$.

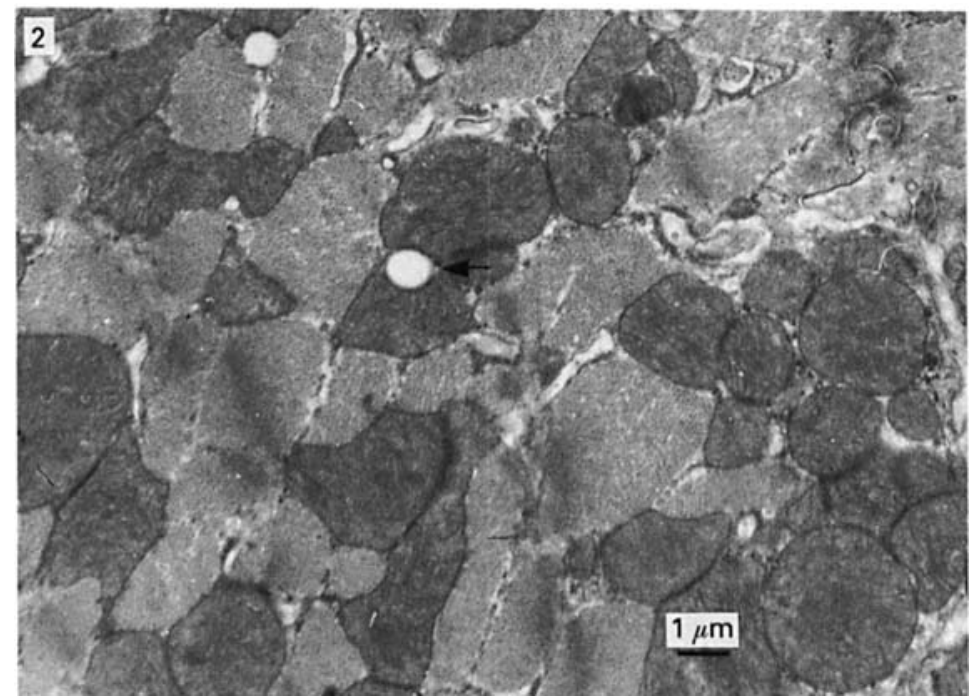

Plate 2. Myocardium from a rat fed on the $20 \mathrm{~g}$ cholesterol $/ \mathrm{kg}$ diet supplemented with $100 \mathrm{~g}$ pectin $/ \mathrm{kg}$ (for details, see Table 1 and p. 187). Only two lipid droplets are seen $(\downarrow) .1 \mu \mathrm{m}(\times 9600)$

Key enzymes involved in the synthesis of triacylglycerols and cholesterol As the availability of substrates along with an inhibition/stimulation of key enzymes in triacylglycerol and cholesterol biosynthesis may contribute to changes of hepatic lipid formation, we examined whether phosphatidate phosphohydrolase and HMG-CoA reductase activities were changed after dietary pectin. Table 8 shows that the phosphatidate phosphohydrolase activity tended to decrease as a result of cholesterol feeding, and in both 
Table 8. Effects of dietary pectin (Pe) and cholesterol $(C h)$ on the activity (nmol/min per $m g$ protein) of hepatic enzymes in rats fed on standard $(S)$ and $20 \mathrm{~g}$ cholesterol $/ \mathrm{kg}(C)$ diets*

(The activity of phosphatidate phosphohydrolase was measured in the microsomal-enriched fraction (PF) and in the cytosolic enriched fraction (SF) after livers of three rats in each group had been pooled. HMG-CoA reductase was measured in the mitochondrial fraction after livers of three rats in each group had been pooled. Palmitoyl-CoA synthetase and palmitoyl-CoA hydrolase activity were measured in the postnuclear fraction with three rats in each group)

\begin{tabular}{|c|c|c|c|c|c|c|c|c|}
\hline \multirow[t]{2}{*}{ Dietary pectin $(\mathrm{g} / \mathrm{kg}) \ldots$} & \multirow{2}{*}{$\begin{array}{l}\text { Treatment } \\
\text { group }\end{array}$} & \multicolumn{2}{|c|}{0} & \multicolumn{2}{|c|}{100} & \multicolumn{3}{|c|}{$\begin{array}{l}\text { Significance of effects in } \\
\text { analysis of variance }(P=)\end{array}$} \\
\hline & & Mean & $\mathrm{SE}$ & Mean & $\mathrm{SE}$ & $\mathrm{Ch}$ & $\mathrm{Pe}$ & $\mathrm{Ch} \times \mathrm{Pe}$ \\
\hline \multirow{4}{*}{$\begin{array}{c}\text { Phosphatidate phosphohydrolase } \\
\text { (EC 3.1.3.4): PF } \\
\text { SF }\end{array}$} & $\mathrm{S}$ & $9 \cdot 61$ & & $9 \cdot 18$ & & & & \\
\hline & $\mathrm{C}$ & $9 \cdot 21$ & & $8 \cdot 80$ & & & & \\
\hline & $\mathrm{S}$ & $2 \cdot 30$ & & $1 \cdot 51$ & & & & \\
\hline & $\mathrm{C}$ & $1 \cdot 33$ & & $1 \cdot 23$ & & & & \\
\hline \multirow{2}{*}{$\begin{array}{l}\text { HMG-CoA reductase } \\
(E C 1.1 .1 .88)\end{array}$} & $\mathrm{S}$ & 0.089 & & $0 \cdot 147$ & & & & \\
\hline & $\mathrm{C}$ & $0 \cdot 055$ & & 0.061 & & & & \\
\hline \multirow{2}{*}{$\begin{array}{l}\text { Palmitoyl-CoA synthetase } \\
(E C 6.2 .1 .3)\end{array}$} & $\mathrm{S}$ & $40 \cdot 82$ & 4.559 & $38 \cdot 10$ & 3.987 & $0 \cdot 791$ & $0 \cdot 341$ & 0.706 \\
\hline & $\mathrm{C}$ & $41 \cdot 33$ & $5 \cdot 151$ & $35 \cdot 18$ & $3 \cdot 711$ & & & \\
\hline \multirow{2}{*}{$\begin{array}{l}\text { Palmitoyl-CoA hydrolase } \\
(E C 3.1 .2 .2)\end{array}$} & $\mathrm{S}$ & $51 \cdot 21$ & 0.363 & $52 \cdot 25$ & $3 \cdot 012$ & 0.851 & 0.238 & 0.359 \\
\hline & $\mathrm{C}$ & $47 \cdot 24$ & $2 \cdot 444$ & $54 \cdot 89$ & $5 \cdot 582$ & & & \\
\hline
\end{tabular}

HMG-CoA reductase, hydroxymethylglutaryl-CoA reductase.

* For details of animals and procedures, see pp. 182-183. For details of diets, see Table 1 .

dietary models pectin resulted in lower enzymic activity. The HMG-CoA reductase activity tended to be increased by pectin in the standard-fed animals, whereas only marginal pectin effect was observed in rats receiving $20 \mathrm{~g}$ cholesterol $/ \mathrm{kg}$ in the diet. Table 8 also shows that cholesterol feeding lowered the HMG-CoA reductase activity both in the 0 and the $100 \mathrm{~g}$ pectin $/ \mathrm{kg}$ groups. No significant changes of the palmitoyl-CoA synthetase activity and palmitoyl-CoA hydrolase activity were observed after pectin feeding.

\section{DISCUSSION}

The present study showed that rats fed on pectin-supplemented diets had significantly lower volumes of lipid in droplets in the cardiomyocytes than control rats. The rats fed on pectinsupplemented cholesterol diets did not have as low a level of lipid droplets in the myocardial cells as the rats fed on the standard diet, but a significantly lower level was found compared with the rats fed on the cholesterol diet without pectin. The study also clearly demonstrated a pectin-induced reduction in the quantity of lipid in droplets in the standard-fed rats. These findings strengthen our previous findings that the amount of cholesterol in the body has an influence on the level of lipid droplets in the myocardium. The lower level of lipid droplets in the myocardial cells of pectin-fed rats might, therefore, primarily be linked to a lower level of body cholesterol. Also, this underscores the reduction of the hepatic cholesterol content by pectin, especially in the cholesterol-fed rats.

The serum cholesterol level was not raised during cholesterol feeding, indicating that the serum cholesterol cannot be used as an indicator of the cholesterol level in the body of rats. That the rats in the present study were receiving and absorbing cholesterol was clearly evident from the data on liver lipids.

Pectin-supplemented diet $(100 \mathrm{~g} / \mathrm{kg})$ significantly reduced the serum cholesterol level in 
both standard-fed and cholesterol-fed rats. These effects of pectin have previously been demonstrated by others (Chen et al. 1981; Vigne et al. 1987; Nishina et al. 1991). The pectin-supplemented diets also attenuated the accumulation of liver cholesterol in the cholesterol-fed rats, and this is in agreement with the findings of Chen et al. (1981).

The effect of pectin on serum cholesterol levels could be due to a number of factors. Of prime significance is the possibility that this effect could be mediated through reduced de novo cholesterol synthesis. It is well documented that $\mathrm{HMG-CoA}$ reductase is rate-limiting in the synthesis of cholesterol under almost all experimental conditions and inhibition of this enzyme has been shown to reduce serum cholesterol levels (Alberts et al. 1980).

The present study showed that dietary cholesterol resulted in an increased liver cholesterol level accompanied by a reduction in $\mathrm{HMG}-\mathrm{CoA}$ reductase activity. This supports other studies where a negative correlation between the concentration of cholesterol or cholesterol ester in the liver and the HMG-CoA reductase activity have been found (Harry et al. 1973; Edwards \& Gould, 1974; Nervi \& Dietschy, 1975; Kelly et al. 1992). Pectin in the standard diet resulted in increased activity of $\mathrm{HMG}-\mathrm{CoA}$ reductase accompanied by reduced hepatic concentration of cholesterol. An increased activity of HMG-CoA reductase after pectin feeding has been found also by Nishina and his coworkers (Nishina \& Freedland, 1990; Nishina et al. 1991). Also interesting to note is that Kelly et al. (1992) found an increased HMG-CoA reductase activity in response to lucerne (Medicago sativa) in the absence of dietary cholesterol. The present study showed that when pectin was given in the cholesterol diet the HMG-CoA reductase activity was only marginally increased whereas the cholesterol content was decreased. We suggest that cholesterol synthesis was not stimulated because of the high level of exogenous cholesterol in the liver (Table 4). These results indicate that the pectin effect on serum cholesterol is not mediated by an inhibition of the reductase. An uncoupling of HMG-CoA reductase and cholesterol $7 \alpha$-hydroxylase occurs in rats treated with dietary cholesterol (Bjørkhem, 1985). Under such conditions HMG-CoA reductase is decreased whereas cholesterol $7 \alpha-$ hydroxylase is increased (Bjørkhem, 1985). Cholesterol $7 \alpha$-hydroxylase was not measured in the present study, but it is reported to increase as a result of a high-fibre diet (Morgan et al. 1974; Nishina et al. 1991). Thus, the reduction in the hepatic cholesterol content and the hypocholesterolaemic effect produced by pectin are primarily explained by increased cholesterol degradation. Some studies have shown that pectin reduces the amount of hepatic triacylglycerol (Chen et al. 1981; Nishina et al. 1991). However, others have found that pectin has no effect on liver triacylglycerol content (Kritchevsky et al. 1988). In the present study dietary pectin and cholesterol increased the concentration of liver triacylglycerol $(P=0.058$ and $P=0.009$ respectively). Plasma triacylglycerol levels are determined by a delicate balance between hepatic triacylglycerol synthesis and secretion on one hand and plasma triacylglycerol clearance on the other. Thus, the increased hepatic triacylglycerol level after pectin and cholesterol feeding (Table 4) could be accomplished by increased triacylglycerol biosynthesis, reduced hepatic lipogenesis and output or enhanced clearance, or a combination of these factors. Inhibition of mitochondrial fatty acid oxidation by cholesterol in the $0 \mathrm{~g}$ pectin $/ \mathrm{kg}$ group and by pectin in the standard-fed rats (Table 6) but not peroxisomal $\beta$-oxidation (Table 7) should emphasize that the changes of mitochondrial fatty acid oxidation have greater impact on the total $\beta$-oxidation of fatty acids than changes in peroxisomal $\beta$-oxidation. Thus, cholesterol and pectin treatment might interfere with both the exogenous and endogenous supply of hepatic fatty acids, affecting their availability for esterification and triacylglycerol synthesis. It should be considered that the increased hepatic triacylglycerol content produced by cholesterol and pectin treatment may be due to inhibited mitochondrial fatty acid oxidation along with increased availability of fatty acids for esterification and triacylglycerol synthesis. 
Administration of S-substituted fatty acid analogues (Skorve et al. 1990) has previously been shown to affect triacylglycerol levels primarily via this mechanism.

The presence of pectin in the cholesterol-fed rats tended to increase mitochondrial fatty acid oxidation (Table 6). This indicates that the hepatic accumulation of triacylglycerol is not mediated by channelling the fatty acids away from fatty acid oxidation toward triacylglycerol synthesis. It is most probably due to a reduced efflux of triacylglycerols from the liver along with increased hepatic lipogenesis, as Rolandelli et al. (1989) demonstrated an increased production of fatty acids as a result of pectin in the diet.

Phosphatidate phosphohydrolase is a key enzyme in regulation of triacylglycerol synthesis (Brindley \& Sturton, 1982). The activity occurs in the microsomes and cytosol and it has been suggested that stimulation of the enzyme activity may be attributed to a translocation of the cytosolic enzyme to the microsomes (Martin-Sanz et al. 1984). In our study the microsomal as well as the cytosolic phosphohydrolase activities tended to be reduced as a result of pectin feeding.

The negative correlation between phosphatidate phosphohydrolase activity and the hepatic triacylglycerol concentration argues against the idea that this esterification step in triacylglycerol biosynthesis is a potential site at which pectin might modulate triacylglycerol synthesis.

In summary, pectin feeding of rats resulted in a lower serum cholesterol level and this also brought about a lower volume of lipid droplets in the cardiomyocytes. Whether these lipid droplets are of importance for development of heart disease should be revealed in future studies. The present study also confirms that pectin influences metabolic processes well beyond the wall of the gastrointestinal tract.

The work has been supported by the Norwegian Council on Cardiovascular Diseases (research fellowship to S. H.) and by the Norwegian Cancer Society (research fellowship to N.W.). The authors are grateful to Svein Kryger, Terje Bjørndal, Edel-Karin Frotjold and Elisabeth Sandvik for technical assistance.

\section{REFERENCES}

Aas, M. \& Daae, L. N. W. (1971). Fatty acid activation and acyl transfer in organs from rats in different nutritional states. Biochimica et Biophysica Acta 239, 208-216.

Alberts, A. W., Chen, J., Kuron, G., Hunt, V., Huff, J., Hoffman, C., Rothrock, J., Lopez, M., Joshua, H., Harris, E., Patchett, A., Monaghan, R., Currie, S., Stapley, E., Alberts-Schonberg, G., Hensens, O., Hirshfield, J., Hoogsteen, K., Liesch, J. \& Springer, J. (1980). Mevinolin: A highly potent competitive inhibitor of hydroxymethylglutaryl-coenzyme A reductase and a cholesterol-lowering agent. Proceedings of the National Academy of Sciences USA 77, 3957-3961.

Anderson, W. A. (1986). Fiber and health: An Overview. American Journal of Gastroenterology 81, 892-897.

Berge, R. \& Farstad, M. (1979). Dual localization of long-chain acyl-CoA hydrolase in rat liver: One in the microsomes and one in the mitochondrial matrix. European Journal of Biochemistry 95, 89-97.

Berge, R. K., Flatmark, T. \& Christiansen, E. N. (1987). Effect of a high-fat diet with partially hydrogenated fish oil on long-chain fatty acid metabolizing enzymes in subcellular fractions of rat liver. Archives of Biochemistry and Biophysics 252, 269-276.

Berge, R. K., Flatmark, T. \& Osmundsen, H. (1984). Enhancement of long-chain acyl-CoA hydrolase activity in peroxisomes and mitochondria of rat liver by peroxisomal proliferators. European Journal of Biochemistry 141 , $637-644$.

Björkhem, I. (1985). Mechanism of bile acid biosynthesis in mammalian liver. In New Comprehensive Biochemistry, pp. 231-278 [H. Danielsson \& J. Sjövall, editors]. Amsterdam: Elsevier Scientific Publishing Co.

Brindley, D. N.\& Sturton, R. G. (1982). Phosphatidate metabolism and its relation to triacylglycerol biosynthesis. In Phospholipids - New Comprehensive Biochemistry, vol. 4, pp. 179-213 [J. N. Hawthorne \& G. B. Ansell, editors]. Amsterdam: Elsevier Scientific Publishing Co.

Brown, M. S., Goldstein, J. L. \& Dietschy, J. M. (1979). Active and inactive forms of 3-hydroxy-3-methylglutaryl coenzyme A reductase in the liver of the rat. Journal of Biological Chemistry 254, 5144-5149. 
Chen, W.-J. L., Anderson, J. W. \& Gould, M. R. (1981). Effects of oat bran, oat gum and pectin on lipid metabolism of cholesterol fed rats. Nutrition Reports International 24, 1093-1098.

Edwards, P. A. \& Gould, R. G. (1974). Dependence of the circadian rhythm of hepatic $\beta$-hydroxy- $\beta$ methylglutaryl Coenzyme A ribonucleic acid synthesis. Journal of Biological Chemistry 249, 2891-2896.

Fuster, V., Badiman, J, J, \& Badiman, L. (1992). Clinical-pathological correlations of coronary disease progression and regression. Circulation 86, Suppl. III, I-II.

Harry, D. S., Dini, M. \& McIntyre, N. (1973). Effect of cholesterol feeding and biliary obstruction on hepatic cholesterol biosynthesis in the rat. Biochimica et Biophysica Acta 296, 209-220.

Hexeberg, S., Willumsen, N., Rotevatn, S., Hexeberg, E. \& Berge, R. K. (1993). Cholesterol induced lipid accumulation in myocardial cells of rats. Cardiovascular Research 27, 442-446.

Judd, P. A. \& Truswell, A. S. (1985). Dietary fibre and blood lipids in man. In Dietary Fibre; Perspectives, Reviews and Bibliography, pp. 23-39 [A. R. Leeds, editor]. London: Libbey.

Kelly, M. J., Thomas, J. N. \& Story, J. A. (1992). Changes in cholesterol accumulation and steroid excretion in response to cellulose, alfalfa or oats in cholesterol-fed rats. Nutrition Research 12, 509-518.

Kritchevsky, D. (1988). Dietary fiber. Annual Review of Nutrition 8, 301-328.

Kritchevsky, D., Tepper, S. A., Satchithanandam, S., Cassidy, M. M. \& Vahouny, G. V. (1988). Dietary fiber supplements: Effects on serum and liver lipids and on liver phospholipid composition in rats. Lipids 23-24, 318-321.

Madar, Z. \& Thorne, R. (1987). Dietary fiber. Progress in Food and Nutrition Science 11, 153174.

Martin-Sanz, P., Hopewell, R. \& Brindley, D. N. (1984). Long-chain fatty acids and their acyl-CoA esters cause the translocation of phosphatidate phosphohydrolase from the cytosolic to the microsomal fraction of rat liver. FEBS Letters 175, 284-288.

Mavis, R. D., Finkelstein, J. N. \& Hall, B. P. (1978). Pulmonary surfactant synthesis. A highly active microsomal phosphatidate phosphohydrolase in the lung. Journal of Lipid Research 19, 467-477.

Morgan, B., Heald, M., Atkin, S. D. \& Green, J. (1974). Dietary fibre and sterol metabolism in the rat. British Journal of Nutrition 32, 447-455.

Nervi, F. O. \& Dietschy, J. M. (1975). Ability of six different lipoprotein fractions to regulate the rate of hepatic cholesterogenesis in vivo. Journal of Biological Chemistry 250, 8704-8711.

Nishina, P. M. \& Freedland, R. A. (1990). The effects of dietary fiber feeding on cholesterol metabolism in rats. Journal of Nutrition 120, 800-805.

Nishina, P. M. Schneeman, B. O. \& Freedland, R. A. (1991). Effects of dietary fibers on nonfasting plasma lipoprotein and apolipoprotein levels in rats. Journal of Nutrition 121, 431-437.

Orekhov, A. N., Tertov, V. V., Novikov, I. D., Krushisky, A. V., Andreva, E. R., Lankin, V. Z. \& Smirnov, V. N. (1985). Lipids in cells of atherosclerotic and uninvolved human aorta. Experimental and Molecular Pathology 42, 117-137.

Orekhov, A. N., Tertov, V. T., Mukhin, D. N., Koteliansky, V. E., Glukhova, M. A., Khashimov, K. A. \& Smirna, V. N. (1987). Association of low-density lipoprotein with particulate connective tissue matrix components enhances cholesterol accumulation in cultured subendothelial cells of human aorta. Biochimica et Biophy'sica Acta 928, 251-258.

Rolandelli, R. H., Koruda, M. J., Settle, R. G., Leskiw, M. J., Stein, T. P. \& Rombeau, J. L. (1989). The effect of pectin on hepatic lipogenesis in the enterally-fed rat. Journal of Nutrition 119, 89-93.

Skorve, J., Asiedu, D., Rustan, A. C., Drevon, C. A., Al-Shurbaji, A. \& Berge, R. K. (1990). Regulation of fatty acid oxidation and triglyceride and phospholipid metabolism by hypolipidemic sulfur-substituted fatty acid analogues. Journal of Lipid Research 31, 1627-1635.

Small, G. M., Burdett, K. \& Connock, M. J. (1985). A sensitive spectrophotometric assay for peroxisomal acylCoA oxidase. Biochemical Journal 227, 205-210.

Tertov, V. V., Orekhov, A. N., Sobenin, I. A., Gabbasov, Z. A., Papov, E. G., Yaroslavov, A. A. \& Smirnov, V. N. (1992). Three types of naturally occurring modified lipoproteins induce intracellular lipid accumulation due to lipoprotein aggregation. Circulation Research 71, 218-228.

Vigne, J. L., Lairon, D., Borel, P., Portugal, H., Pauli, A. M., Hauton, J. C. \& Lafont, H. (1987). Effect of pectin, wheat bran and cellulose on serum lipids and lipoproteins in rats fed on a low-or high-fat diet. British Journal of Nutrition 58, 405-413. 